Scientia Militaria vol 40, no 3, 2012, pp.1-12. doi: 10.5787/40-3-1029

\title{
Between history, amnesia and selective memory: The South African armed forces, a century's perspective
}

\author{
Ian van der Waag and Deon Visser ${ }^{\bullet}$
}

2012 has a double significance for this year sees the centenary of the founding of the African National Congress (8 January) and of the creation of the Union Defence Forces (1 July), two organisations that have for much of the twentieth century shared a contested history. Yet, in a remarkable bouleversement, South Africa has come through this difficult past and, over the past two decades, a new South African society has been recreated following an interesting period of adjustment following the end of the Cold War and the growth of democracy in the developing world. These changes have necessarily affected her armed forces and the roles defined for them. Some commentators, particularly in the years immediately following 1994, asserted that military power had lost all of its vaunted, Cold-War importance in a new postmodern environment. Others still, recognising future challenges, argued that South Africa, beset with far-reaching socioeconomic crises, could no longer afford the burden of military forces. Most scholars agree now that these perspectives were short-sighted and that, while the risk of major conflict has receded, the events of 9/11, and its consequences, demonstrate that the continental and international landscapes are less certain, less stable and less predictable, than that for which many had hoped. Clearly, South African interests are intertwined inextricably in regional and global affairs and if she is to protect these interests and ensure her security, she must maintain credible military force capable of meeting an array of contingencies. It was with this in mind that the strategic arms deal, since the subject of much debate, was passed by parliament: ${ }^{1}$ the promise of a full technological transformation, to accompany the human transformation, offered.

Proff Ian van der Waag and Deon Visser, Department of Military History, Stellenbosch University, are the guest editors of this special issue. 
Today the South African National Defence Force (SANDF), numbering some 74,596 fulltime members, confronts not only the culmination of a long and tortuous, post-1994, integration and transformation processes, but also further calls to deploy in support of multinational peace operations. South African peace operations started in 1996 with the posting of two officers to the UK Multinational Division in Bosnia, followed by the rather difficult intervention in Lesotho in 1998, before escalating rapidly from 1999 with deployments, as part of various SADC, AU and UN operations, to Burundi, Mozambique, the Democratic Republic of Congo, the Comoros, the Central African Republic, Ethiopia and Eritrea, Uganda, and the Sudan. ${ }^{2}$ Moreover, South Africa, as part of her broader goal to restore and establish peace and stability on the continent of Africa, contributes to the African Standby Force (the AU's rapid reaction force) and the associated SADC brigade, structures that were created in 2006. ${ }^{3}$ Perhaps surprisingly, South Africa now occupies the tenth position on the ranking of UN peacekeeping contributions. In terms of role definition the SANDF may be deployed in order to '[1] preserve life, health or property in emergency or humanitarian relief operations; [2] ensure the provision of essential services; [3] support any department of state, including support for purposes of socio-economic upliftment; and [4] effect national border control. ${ }^{4}$ This emphasis on humanitarian and developmental missions represents a major shift in approach away from warfighting and the harder military roles of the 1970s and 1980s and early-1990s, cf. Warwick and Scholtz in this volume. ${ }^{5}$

The ANC centennial activities included a conference and several publications. ${ }^{6}$ On the other hand, the centenary of the founding of the Union Defence Forces (UDF), difficult to commemorate as it may be, was lost amidst the politics of a new national memory. The armed forces of South Africa were established on 1 July 1912, when the armed forces of the four British colonies came together to form the Union Defence Forces of the new Union of South Africa. This integration, the first of three amalgams, followed shortly after the Anglo-Boer War (1899-1902) and was heralded to be an example of how at least the majority of Afrikaans and Englishspeaking South Africans, setting aside their historical differences, were drawn into new military structures in the spirit of "Union". A second transformation followed the 1948 election, the accession to power of the South African National Party and the creation of a purportedly South 
African Defence Force (SADF). The Afrikaner nationalist interpretation focussed on the political history of the glorious march of Afrikaner nationalism toward the creation of "South African" structures and eventually the advent of the republic in 1961. Events in the armed forces, and similar processes that played out elsewhere, were seen to be axiomatic. It was sufficient for nationalist scholars to note simply that 1948 allowed a triumphant nationalist party to reshape the UDF into a supposedly more "South African" force, after a thirty-year, Anglophone sojourn in the jungles and deserts of the two world wars. ${ }^{7}$ A third transformation, which followed the first, broad-based, democratic elections in 1994, led to the formation of the SANDF in terms of the negotiated 1993 Interim Constitution and saw the integration of no less than eight forces on 27 April 1994. The largest of these were the SADF and Umkhonto we Sizwe (MK), the armed force of the African National Congress. The others were the Transkei Defence Force (TDF), the Bophuthatswana Defence Force (BDF), the Venda Defence Force (VDF), and the Ciskei Defence Force (CDF) - collectively the TBVC defence forces. These were the armed forces of the independent states (the "independent homelands") of the Transkei, Bophuthatswana, Venda and the Ciskei. The Azanian People's Liberation Army (APLA), the paramilitary wing of the Pan African Congress, integrated in 1997. A late addition, too, was the KwaZulu Self-Protection Force (KZSPF), the paramilitary wing of Inkhatha that opposed MK in Zululand and on the Rand.

The SANDF was to be a radical break with the past, the armed forces would be subject to the civil power, the state would only be able to apply power in terms of a new, negotiated constitution (grundnorm), and the defence force, now recognised to be an integral part of South African society, would transform from an institution based on racial privilege into one of equal individuals, distinguished only by merit. These processes, as Fourie and Neethling argue in this volume, were complex and remain so. Moreover, 1994 was a watershed year and the 'pre-history' remains contested. ${ }^{8}$ (This led to a degree of amnesia not dissimilar to the American memory loss after the Vietnam War, though perhaps not as acute. ${ }^{9}$ ) As both a consequence and manifestation of this amnesia, the centenary of the founding of the UDF has slipped past quietly.

Moreover, a discussion of South African military history, a narrative that embraces the history of all of the ancestral forces of the new SANDF, 
does not have the luxury of engaging with a wide body of historical literature. The former SADF, of all of the ancestral forces, has the best documented history. Much has been written on various aspects of the SADF's history, from her four colonial ancestors to her establishment in July 1912, through the vicissitudes of two World Wars and Korea to the most recent Southern African War. The SADF employed a professional team of historians intermittently since 1914 and permanently from 1953, and from the 1970s, the SADF made active use of her history in an attempt to counter growing international isolation. ${ }^{10}$ The SADF's long history, and her speedy entry and distinguished service in two World Wars and the Korean War, were emphasised. ${ }^{11}$ No historian, official or otherwise, has to date produced a comprehensive, systematic, single-volume history of the former SADF. ${ }^{12}$ However, fortuitously, the SANDF Documentation Centre, custodian of South African military records generated since the founding of the Union Defence Force in 1912, houses more than sixty linear kilometres of records. There is hardly an aspect of this history that cannot be interrogated and, as numerous researchers find, query opens the trapdoor to a vast, sunken, documentary labyrinth of a virtually forgotten past.

Sadly little research has been undertaken on the history of the other ancestral forces: with the exception of a few works, no historical studies have been published on either of the non-statutory forces or any of the TBVC defence forces. ${ }^{13}$ Several reasons have been suggested for this imbalance in historical work. These include the long period of voicelessness on the part of some of the forces, within South Africa at least. International experience shows that there are different ways to deal with a troubled history. Some, like Poland and post-Franco Spain, opt for an almost full historical amnesia and attempt to 'draw a thick line under the past. ${ }^{14}$ Conversely, the Germans, who have experienced two rounds of 'pastbeating', have investigated, exposed, recriminated and reconciled. They have dealt with their past through trial and purge and truth commission and the systematic opening of files, especially those of the Stasi, the former East German secret police. Others, like South Africa and Chile, find some middleplace with a truth and reconciliation commission, processes that are inevitably controversial, often one-sided, and never complete. ${ }^{15}$ As James and Van de Vijver have argued, in South Africa 'the testimonies that emerged during the TRC process do not, obviously, constitute memory.' Not only was the work of the Commission limited to acts of gross human rights 
violations during the period from 1960 to 1994, but only some victims testified and only those perpetrators, from all sides, who applied for amnesty, told their stories. Moreover, the dead, for obvious reasons, could not appear; their memories being lost forever. While the Report of the South African Truth and Reconciliation Commission constitutes perhaps the largest, single contribution to the public memory of the struggle for South Africa, it remains necessarily incomplete and has to be primed in unison with the careful study of biography and memoir, contemporary commentary and press reportage, and fiction and artistic impression. ${ }^{16}$

This leads on to the matter of sources. As far as primary sources are concerned, much of the history of the ANC is locked up in a collection of photographs and documents housed at the Mayibuye Centre at the University of the Western Cape in Cape Town. Here the largest single collection is the records of the International Defence and Aid Fund for Southern Africa (IDAF), which was shipped from London to Cape Town in 1992 and filled two containers. This was the documentary residue of the IDAF's 36 year history. ${ }^{17}$ Given the dominance of politics in revolutionary guerrilla wars, most of the rest of the ANC records at the Mayibuye Centre presumably cover the political rather than the military component of the ANC's liberation struggle. Moreover, the ANC seemingly grants only limited access to its files. This may foster perceptions that a full reading of the records will show how relatively small, and perhaps also insignificant, the actual armed resistance to the apartheid government was; whereas many post-1994 leaders have built upon the fiction of a large, coordinated, wellled anti-apartheid resistance. Compared to the intense wars of national liberation waged elsewhere in southern Africa, in Namibia, Angola, Mozambique and Zimbabwe, and further a field in Algeria, Indo-China and several South American states, the ANC's armed struggle appears insignificant indeed in terms of scale, casualties and impact. ${ }^{18}$ There are, therefore, seemingly no trapdoors leading to vast, unexplored, sunken archival labyrinths.

Rocky Williams, himself an MK operative, blamed 'a lack of ... consolidated research material' for his own failure in 1994 to produce a 'more thorough analysis of MK's military history'. ${ }^{19}$ In 2000 he ascribed this dearth of sources to: 
the ethnic composition of... historians... most of whom tend to be white English-speaking males... [and] the extent to which the black South African military experience in the twentieth century has largely been ignored... the lack of a written tradition inherent in any young army; the severe censorship and political restrictions characterising the period during which MK operated as a guerilla (sic) army, and the lack of resources required presently to mount a sustained study of MK since its inception'. ${ }^{20}$

Here he significantly omitted a factor which he mentioned in his 1994 chapter in The long march, namely the lack of a developed military underground within the country, and a lack of public detail as to what constituted $\mathrm{MK}$ in terms of units, engagements, training, deployment patterns, and social composition (understandable in any guerilla (sic) army that had to operate in difficult conditions of illegality and clandestineness) ${ }^{21}$ More recently, Anthea Jeffery encountered similar difficulties regarding the sources. She based her People's War, a history of the armed struggle in South Africa, on a number of ANC publications, Radio Freedom broadcasts, and a set of interviews conducted mostly in the 1990s. Yet, as she notes, 'none of these sources could suffice to stitch together the story of the ANC's people's war, for none dealt adequately with all its major aspects', and she had to resort perforce to extensive use of press coverage, inadequate as it too is as an historical source, and, in particular, to the press-clipping collection of the South African Institute of Race Relations. $^{22}$

The first noteworthy history of MK, Barrell's MK: The ANC's Armed Struggle, ${ }^{23}$ appeared in 1990. Prior to that only brief summaries of its history appeared in the political literature of the 1980s. ${ }^{24}$ Barrell's work was followed by a commemorative magazine on MK on occasion of its $30^{\text {th }}$ anniversary in $1991 .{ }^{25}$ MK Commander Ronnie Kasrils's autobiographical work Armed and dangerous ${ }^{26}$ followed on the eve of the new South Africa. The year of liberation, 1994, saw inter alia the appearance of a journal article by Tsepe Motomi ${ }^{27}$ and a short book chapter by Rocky Williams ${ }^{28}$ on aspects of MK’s history. In December 1995 the Mayibuye Centre launched a conference on "The Beginning of the Armed Struggle in South Africa: The Launch of Umkhonto we Sizwe" to take stock of MK's meagre historiography, identify the gaps, bring the nature and location of sources on MK's history to the attention of researchers, and to try and get the ball rolling to record MK's history in print. No major history of MK flowed 
from this effort. In 2006 Williams followed up his earlier work with a brief monograph on South African Guerrilla Armies: The Impact of Guerrilla Armies on the Creation of South Africa 's Armed Forces, ${ }^{29}$ in which he deals with the contribution of the Boer forces and MK in the creation of new defence forces (the UDF in 1912 and the SANDF in 1994) in different phases of South Africa's history. In 2011, in the run-up to the ANC's $100^{\text {th }}$ birthday, Janet Cherry produced a concise (160 pp) pocket history of MK entitled Umkhonto weSizwe. This, intentionally 'popular account which is both a critical, anti-war history and a history that is profoundly empathetic to the experiences of ordinary soldiers fighting for a just cause ${ }^{30}$, is a welcome addition to the existing literature as it outlines the various strategic phases of MK's history within the Cold War context, dealing with MK's successes and failures and the personal experiences of MK members. Besides these pro-ANC writings, there have of course been a number of works by authors not sympathetic to ANC or disgruntled former ANC cadres. ${ }^{31}$

In a newly-released centennial publication on the ANC, Philip Bonner notes the establishment of MK as a recognisable milestone in the growth of non-racialism within the ANC. ${ }^{32}$ This theme is, however, not addressed in that publication. The book contains no systematic history of MK and only two out of its fifteen chapters make notable reference to MK. ${ }^{33}$

The diverging individual narratives of the constituent components (integrated former militaries) of the SANDF perhaps make it difficult for National Government and the SANDF to raise enthusiasm for festivities and celebrations according to a new national narrative during its centennial year. Bonner stresses that 'as history becomes more politically serviceable, it becomes more boring... since it is always the authorised version of the established grand narrative to which appeal is made'. ${ }^{34}$ The grand narrative becomes so sterile that it touches nobody's heart. Bonner further contends:

As history becomes more politically instrumental, it tends to be more homogenised and stripped down. Inconsistencies, the ignoble, even the human, get airbrushed out. Most critically, failures cannot be adequately addressed because the grand narrative of struggle is ultimately heroic and correct. ${ }^{35}$

Chris Saunders observes that scholars who wrote new histories of tropical African countries upon their gaining of independence by the 1960s 
mostly portrayed the liberation struggles of those countries as struggle by a united people under a great leader, with independence as their collective goal. ${ }^{36}$ This is not the true of post-Apartheid South Africa. Instead, he argues:

a nationalist interpretation of our recent history has begun to develop in public discourse. This emphasises the armed struggle to play down the negotiated settlement that was reached, based as it was on a series of compromises. The primary role of the ANC in the struggle, the heroism of its leaders and the importance of its armed wing, Umkhonto we Sizwe (MK), are emphasised. Like the much more extreme version in Zimbabwe... this is a set of myths about the past. ${ }^{37}$

If not quite without bias himself, ANC/MK stalwart, Rocky Williams, acknowledges this distortion of MK's history, stating that 'histories (of southern African twentieth century guerilla (sic) armies) are often 'official' versions and, as such, reflect the ideological bias of the ruling party. ${ }^{38} \mathrm{He}$ continues:

As the army of the country's largest political movement, MK is admired by the supporters of the ANC... Within this scenario, its relatively high levels of legitimacy and recorded operational experience are intimately interwoven with myth and popular sentiment. ${ }^{39}$

The lack of systematic histories of the former non-statutory and TBVC ancestral forces of the SADF must be addressed. Apart from the obvious historiographic advantages of recording these histories, such works should go a long way toward morale-building and the fostering of a unified esprit de corps within the SANDF. While accuracy and objectivity will have to be stressed, the writers of these histories should not become gridlocked with socalled facts, but should aim to present narrative type history that may also be read with ease and pleasure. A project encapsulating the history of these seven forces, either as a single publication or in a series of small volumes, should be launched now. Historians have to be identified, the archival sources have to be arranged, catalogued and rendered accessible to the researchers, life history interviews have to be held, and, perhaps most importantly of all, a patron has to be found for such a project. Time is, however, of the essence. As time passes memories fade and accuracy is lost in the first person accounts, which are so important. Documents not 
otherwise transferred to archives depots for safe custody may be lost forever. Such a project will also bring into existence the first series of general histories on the military forces of South Africa and would supplement the existing secondary sources, which, for certain periods are vague and inadequate to say the least. ${ }^{40}$

The essays published in this volume were written between 2006 and 2012. Employing differing methodological approaches, they reflect an assessment of South Africa's varied military past. Some indicate strong attachment to historicist conceptions of historical study, others, with an emphasis on narrative and event, are concerned with structures and social forces in their quest for a "military historical social science." Fundamental difference as to what constitutes military history, and military history as a social science, clearly exist. History is after all tolerant of variety, even of quirkiness and idiosyncrasy. 'In History's house', Richard Cobb declared, 'are many mansions. ${ }^{41}$ But, most of the essays in this volume focus on the UDF and SADF.

Assessing change and continuity in South Africa's armed forces before and after 1994 is a vast undertaking. While the South African military had to grapple with transformation of different hue for much of the twentieth century (as many militaries, in fact, did) its complex ramifications were brought into sharper relief during the three periods of the 1910s, 1940s and 1990s. The military, in many ways a barometer and a window into society, encapsulates both the political transformative impact and the continuities which link the histories of 1912, 1948 and 1994, of the making of the Union, the dawn of Apartheid, and the creation of a second "New South Africa" within the space of some 80 years. The South African experience is rich and this makes study both fascinating and rewarding.

$1 \quad$ J Sylvester \& A Seegers. "South Africa's Strategic Arms Package: A Critical Analysis”. Scientia Militaria 36/1. 2008. 52-77.

$2 \quad$ Charles Ross. "Peace support operations". South African Soldier 16/9. 2009. 10-15. See also Theo Neethling. "Southern African Military Interventions in the 1990s: The Case of SADC in Lesotho”. In L du Plessis \& M Hough (eds), Managing African Conflicts: The Challenge of Military Intervention, Pretoria: HSRC, 2000.

3 Africa Union. Roadmap for the Operationalization of the African Standby Force. Addis Ababa: AU, 2005 and T. Neethling. "Shaping the African 
Standby Force: Developments, Challenges and Prospects”. Military Review 85. 2005.

Section 18 of the Defence Act (42 of 2002).

See, for example, Bruce Thobane, Theo Neethling \& François Vrey. "Migration from the OAU to the AU: Exploring the quest for a more effective African peacekeeping capability.” Supplementa ad Scientia Militaria II. 2007 and Laetitia Olivier, Theo Neethling \& Benjamin Mokoena. "Pursuing human security in Africa through Developmental Peace Missions: Ambitious construct or feasible ideal?”. Supplementa ad Scientia Militaria III. 2009. Thula Simpson. "The ANC at 100". South African Historical Journal 64/3. 2012. 381-92. See C. Saunders's review article entitled "The ANC's 100 years: Some recent work on its history in historiographical context”. Historia 57/2. 2012.

I van der Waag. "Contested histories: official history and the South African military in the $20^{\text {th }}$ century." In J Grey (ed), The Last Word? Essays on Official History in the United States and British Commonwealth, Westport, Connecticut \& London: Praeger, 2003, 27-52.

As Hilton Hamann has noted, 'part of the spoils is that the victors get to rewrite history to suit themselves.' H. Hamann. Days of the Generals: The untold story of South Africa's apartheid-era military generals. Cape Town: Zebra, 2001, xi. On the battle for the history see also Todd Cleveland. "'We still want the truth': The ANC's Angolan detention camps and postapartheid memory”. Comparative Studies of South Asia, Africa and the Middle East 25/1. 2005 and Jacob Dlamini's challenge in terms of what he calls the 'comforting fiction of our past' in his Native Nostalgia. Johannesburg: Jacana, 2009. George C. Herring. America's Longest War: The United States and Vietnam, 1950-1975, eth ed. Boston, etc: McGraw Hill, 2002, 347-348. Van der Waag, "Contested histories...” op. cit., p. 42.

"Editorial”. Militaria 25/1. 1995. 2.

It may be noted here that David Williams, Springboks, Troepies and Cadres: Stories of the South African Army 1912-2012, Cape Town: Tafelberg, 2012, is not history in this sense. Jakkie Cilliers \& Markus Reichart. "The History of the Homeland Armies”. In Jakkie Cilliers \& Markus Reichart (eds), About turn: The Transformation of the South African Military and Intelligence, Halfway House \& Johannesburg: Institute for Defence Policy, 1996 and Tom Lodge. "Soldiers of the Storm: A Profile of the Azanian People's Liberation Army”. In Jakkie Cilliers \& Markus Reichart (eds), About turn: The Transformation of the South African Military and Intelligence, Halfway House \& Johannesburg: Institute for Defence Policy, 1996. Timothy Garton Ash, The File: A Personal History. New York: Vintage, 1997, 219-220.

15 Heribert Adam \& Kanya Adam. "The Politics of Memory in Divided Societies.” In Wilmot James \& Linda van de Vijver (eds), After the TRC: reflections on truth and reconciliation in South Africa, Cape Town: David Philip, 2000, 32-47. 
Wilmot James \& Linda van de Vijver. "Introduction”. In James \& Van de Vijver (eds) op. cit., p. 1.

Horst Kleinschmidt. The story of IDF. $<$ http://mayibuyearchives.org/index.php?module $=$ cms\&action=showfulltext\&i d=gen20Srv23Nme0 1509 1257318325\&parent=gen20Srv23Nme0 $8463 \quad 12$ 57317844> Accessed on 6 on December 2012.

André Wessels. "A different kind of decolonization: The struggle for South Africa, 1961-1994”. Journal for Contemporary History 36/3. 2011. 49.

R Williams. "The other armies: writing the history of MK". In I Liebenberg, et al (eds), The long march: The history of the struggle for liberation in South Africa, Pretoria, etc: Haum, 1994, 23.

R Williams. "The other Armies: A brief historical overview of Umkhonto We Sizwe (MK), 1961-1994”. Military History Journal 11/5. 2000. <http://samilitaryhistory.org/vol115rw.html> Accessed on 28 November 2012. Williams. "The other armies: writing the history of MK" op. cit., p. 24.

Anthea Jeffery. People's War: New Light on the Struggle for South Africa. Johannesburg \& Cape Town: Jonathan Ball, 2009, 35-40.

H Barrell. MK. The ANC's Armed Struggle. Harmondsworth: Penguin, 1990.

Williams. "The other armies: writing the history of MK" op. cit., p. 24.

Umkhonto We Sizwe. Umkhonto We Sizwe 30 Anniversary Souvenir Magazine. Johannesburg: Umkhonto We Sizwe, 1991.

R Kasrils. 'Armed and Dangerous': My Undercover Struggle Against Apartheid. Oxford: Heinemann, 1993.

T Motumi. "Umkhonto We Sizwe: Structure, Training and Force Levels (1984 to 1994)". African Defence Review 18.1994. $<$ http://www.iss.co.za/pubs/asr/ADR18/Motumi.html $>$ Accessed on 28 November 2012.

Williams. "The other armies: writing the history of MK" op. cit. (A slightly different version of this chapter was published as a journal article in 2000 - see Williams. "The other Armies: A brief historical overview of Umkhonto We Sizwe (MK), 1961-1994” op. cit.

R. Williams. ISS Monograph 127: South African Guerrilla Armies: The Impact of Guerrilla Armies on the Creation of South Africa `s Armed Forces. Pretoria: Institute for Security Studies, 2006. See also I Liebenberg. "The Integration of the Military in Post-liberation South Africa: The Contribution of Revolutionary Armies”. Armed Forces and Society 24/1. 1997. 105-132.

Janet Cherry. Umkhonto weSizwe. Johannesburg: Jacana Media, 2011, 12.

See Saunders, “The ANC's 100 years...” op. cit., p. 431.

Philip Bonner. "Fragmentation and Cohesion in the ANC: The First 70 Years”. In Arianna Lissoni, Jon Soske, Natasha Erlank, Noor Nieftagodien \& Omar Badsha (eds), One Hundred Years of the ANC: Debating Liberation Histories Today. Johannesburg: Wits University Press/Cape Town: South African History on Line, 2012, 10.

Hugh Macmillan, "Shishita: A Crisis in the ANC in Exile in Zambia, 1980 1981”. In Lissoni, Soske, Erlank, Nieftagodien \& Badsha (eds) op. cit., pp. 233-253. Vladimir Shubin, “Comrade Mzwai”. In Lissoni, Soske, Erlank, Nieftagodien \& Badsha (eds) op. cit., pp. 255-274. 
34 Bonner, "Fragmentation and Cohesion in the ANC...” op. cit., p. 2. Ibid.

Saunders. “The ANC’s 100 years...” op. cit., p. 431.

Ibid.

Williams. "The other Armies: A brief historical overview of Umkhonto We Sizwe (MK), 1961-1994” op. cit.

39 Williams. "The other armies: writing the history of MK" op. cit., p. 23.

40 "Editorial”, Militaria 25/1, 1995, p. 2.

$41 \quad$ Richard Cobb quoted by Ash op. cit., p. 69. 